\title{
Benefits Of Student Attention in The Implementation Of Learning
}

\author{
Hariyanto \\ Raden Wijaya Wonogiri State Buddhist High School, Central Java \\ buddha_wng@yahoo.com
}

Article History: Received: 10 November 2020; Revised 12 January 2021 Accepted: 27 January 2021; Published online: 5 April 2021

\begin{abstract}
Students' attention in learning is one of the factors that influence the success in implementing learning. The implementation of learning is not fully planned, it is evident in the implementation of learning that many students do not focus or pay attention to learning. Poor student attention will be one of the causes of failure in achieving learning objectives. The data analysis prerequisite test was conducted using normality and linearity tests. The hypothesis testing was done using a simple linear regression analysis. The result of research showed that the data of learning and learning achievement was valid, reliable, and distributed normally. Effect of learning attention on the learning achievement $\mathrm{i}$ wasindicated by $\operatorname{sig}(\mathrm{p})<\alpha$ or $0.000<0.05$. Learning attention contributed to the learning achievement of Buddhism education by $45 \%$.
\end{abstract}

Keywords: learning attention and learning achievement

\section{Introduction}

Improving the quality of education is an important part of an effort to improve the quality of human resources in terms of abilities, personality, and responsibilities as citizens. Education is a basic need that must be met by humans. Education is a conscious human effort to improve his quality, both individually and collectively.

Education has a function and a purpose. The function of education is to prepare people as workers and good citizens. The purpose of education according to Law Number 20 of 2003 Chapter II Article 3 states that the purpose of education is to provide the knowledge and abilities needed by students in everyday life. A person who follows education is expected to form and develop attitudes, behaviors, and knowledge and skills that are necessary and useful for self-continuity and progress in society, nation and country.

The learning success of students is related to the high value achieved, absorption, and achievement in the form of report cards. Learning achievement is influenced by the environment of students who live and receive educational experiences.

Themain omponen that must be present in conveying science are educators (teachers), learning materials (materials), and learners. Teachers in the classroom are required to master the class situation because of the different characteristics of the learners. The characteristics of different learners also cause differences in learners in receiving learning materials. Learning materials will be well received if the learner pays attention to what the teacher is conveying. According to Hoy (2007: 251) "In sensory memory, control processes of perception; attention and recognition determine what will be transferred to working memory and held briefly for further use". Attention is the first step in the learning process. In addition, attention plays an important role in the stimulus in this case the learning materials received by memory sensors. The material delivered by buddhist education teachers is acceptable if the attention of the learner is focused.

Internal learning problems related to the personality condition of learners, both physical and mental. With regard to physical aspects will certainly be relatively easier to observe and understand, compared to the dimensions of mental or emotional dimensions. While in reality, learning issues are more related to the mental or emotional dimension. Bellas, F., Becerra, J. A., \& Duro, R. J (2008), Sobocan, M., Turk, N., Dinevski, D., Hojs, R., \& Pecovnik Balon, B. (2017).

A teacher will encounter many problems related to the mental or emotional problems of the learner. One of the mental or emotional problems of learners during learning is attention. The attention of learners in learning has an important role. Attention to the lesson will arise in the learner if the teaching material is in accordance with his needs. If the teaching material is perceived as something needed, it is necessary to learn more or needed in everyday life will generate motivation to learn it. If this natural attention does not exist then the learner needs to be raised his attention Cordner, C. (2016). 
Attention is a concentration of psychic energy aimed at an object. The attention of learners in a learning centered on the delivery of materials given by the teacher. Learners strive to raise attention to all the messages learned. These messages are the content of learning that is usually in the form of sounds, colors, shapes, and motions delivered by teachers. Based on a UC Davis study (Science Daily: 2009) shows that attention problems can hinder learning and early psychiatric disorders like this are partly the cause of future failures. According to Rusmita Kurniati (2009) the attention of learners includes the behavior of learners in the teaching and learning process in the form of: willingness of learners to listen to explanations from teachers, perform assignments given by teachers, record important materials, view images or media used, listen to friends' opinions, answer teacher questions, and be calm in class.

Indicators of learner's attention can be shown in the activities carried out in the learning. If the learner is really paying attention, then the learner will follow and carry out the learning activities well. States that learning activities include listening, looking, fingering, blending, tasting, writing or recording, reading, summarying, observing, remembering, and practicing Skwarchuk, S.-L., Sowinski, C., \& LeFevre, J.-A. (2014).

Learners will follow and carry out all learning activities in the classroom if the learner pays attention to the learning that is being done. Learners do not do any other. The attention of learners who are focused on learning causes the message of learning to be well received by the learner, so that there will not be miss communication that can have bad consequences. In addition, the attention will make it easier for learners to do the questions in accordance with the learning materials that have been submitted so as to obtain good learning achievements as well.

Learners strive to raise attention to learning activities, in addition, teachers can also strive to raise attention, by using varied learning methods, using interesting media according to the material, using non-monotonous language styles and using guiding questions. States that each student has different characteristics and has different attention. That attention can be divided into spontaneous attention and intentional attention, static and dynamic attention, concentric and distributive attention, narrow and broad attention, as well as fictitious and fluactive attention Larouche, M., Côté, G., Bélisle, D., \& Lorrain, D. (2014).

From the various learning materials provided by the teacher, there is one subject that is less attention-grabbing, namely Buddhist Education. Buddhist education is considered difficult because it uses a foreign language and is not interesting so that students are less eager to learn Buddhism Education.

Learners who do not pay attention to the explanation of Buddhist Education teachers, will not be able to solve the questions given, because the lessons of Buddhist Education are interconnected. Learners will have difficulty in receiving the next learning material if the learner is left behind in participating in Buddhist Education learning.

The fact shows that students of Buddhist education, especially in Wonogiri Regency when carrying out learning in the classroom pay less attention to learning materials. Students easily forget the material of Buddhist education is one of the reasons the results of learning Buddhism education is not optimal, proven by the achievement score of Learning Buddhism is still low at 6.5.

"attention is the activeness of the soul directed towards an object, both inside and outside of itself". The attention is related to the needs, and the symptoms of attention are related to other mental functions DA, Z., ENGELBERG, J., \& GAO, P. (2011). Tthere are two notions of concern. First, attention is the concentration of psychic energy to an object. Second, attention is a lot of little awareness that accompanies something activity that is done Teixeira, A. R., Tome, A., Roseiro, L., \& Gomes, A. (2018). Whereas according to Moran, A. (2017) states that attention is an activity that a person does in relation to the selection of stimuli that come from his environment. Other opinions expressed by Mc. Cown (Sri Rumini, 1998, p. 125) states that attention is the process of taking action on information that will be transformed in various ways.

Based on some of the above understandings, attention is an activity carried out by someone who is focused on an object or set of objects. The attention of learners in learning is the activities of learners carried out in the classroom aimed at ongoing learning (no other activities are carried out by learners).

According to Stavrinos, G., Iliadou, V.-M., Edwards, L., Sirimanna, T., \& Bamiou, D.-E. (2018) attention can be divided into several kinds, namely:

1. Spontaneous attention is also called genuine attention or direct attention, is attention that arises by itself, caused by being attracted to something and not driven by willpower.

2. Static attention is a fixed concern for something.

3. Concentrated attention (attention is concentrated), i.e. attention that is directed only to one particular object (problem). 
4. People who have narrow attention can easily focus their attention to a limited object, even in a crowded environment. Meanwhile, people who have widespread attention are easily attracted by the events around them.

5. Fictitious attention (inherent attention) is attention that is easily focused on a thing and it can be said that the attention can be attached long to the object.

Factors that influence attention according to Gareeva, A. E., Sharafiev, R. R., Akhmetova, E. A., Nasibullin, T. R., Fakhurtdinova, Z. R., Yuldashev, V. L., \& Asadullin, A. R. (2020) namely:

1. Certain carriers related to reacted objects, then little or much attention will arise to a particular object.

2. Exercises and habits although there is no talent for carrying about a field, but because of a result rather than exercises or habits, can cause easy attention to a particular field.

3. Necessity is encouragement, while it has a purpose that must be poured out on it. Thus the attention to these things must exist, in order to achieve a goal.

4. Obligations contained responsibilities that must be fulfilled by the person concerned. And for him who is aware of his obligations and is aware of his obligations.

5. Healthy or physical, fresh body does not greatly affect the attention to an object.

6. Mental state, feelings, fantasies and thoughts, such as noise, commotion, chaos, temperature, socioeconomic, and beauty can affect attention.

7. Strong or not arousal of the object itself if an object gives a strong stimulant, the possibility of attention to the object is large. On the contrary, if the object gives a weak stimulant, its attention is also not so great.

Dao, P., Iwashita, N., \& Gatbonton, E. (2016) states that the attention of learners arises driven by curiosity. Therefore, this curiosity needs to be stimulated so that learners always pay attention to the subject matter provided. In order for students to be interested and pay attention to the subject matter delivered, teachers can always encourage the involvement of learners in the teaching and learning process or in learning activities. Mentions that learning activities include Ma, S., Sigal, L., \& Sclaroff, S. (2016):

1. Listen

2. Looking at

3. Fingering, fingering, and tasting

4. Write or record

5. Reading

6. Create a summary and underline

7. Observe tables, charts, and charts

8. Remembering

9. Thinking

10. Practice or practice

Learning is a process of changing behaviors involving the body and soul so as to produce changes in terms of knowledge, understanding, values and attitudes carried out by an individual through practice and experience through interaction with the environment which is hereinafter called learning outcomes.

According to Muijs \& Reynolds (2011) ".... Learning can be defined as an experiemental process resulting in a relatively permanent change in behavior that cannot beexplained by temporary states, maturction, or innate response tendencies". Based on the quote above it says that: "... learning can be defined as the result of an experimental process in a relatively permanent behavioral change that cannot be pronounced with a momentary statement.

Learning outcomes are also calledacademic achievement. Understanding learning achievements from Good (1945: 27) are: "knowledge attained or skills developed in the school subjects are usually designated by test scores or by marks assigned by teachers, or by both. The achievement of pupils in the so called "academic" subjects, such as reading arithmatic, and history, as contrasted with skills developed in such areas as industrial art and physical education". 
Learning outcomes are things that can be seen from two sides, namely the student side and from the teacher side. In terms of students, learning outcomes are a better level of mental development when compared to the time before. The level of mental development is manifested in the types of cognitive, affective, and psychomotor domains. In terms of teachers, learning outcomes are a time of learning Sinclair, P. M., Kable, A., Levett-Jones, T., \& Booth, D. (2016). The result of learning is when a person has learned there will be a change in behavior in the person, for example from not knowing to know, and from not understanding to understanding Brinson, J. R. (2015). So the result of learning is a tangible result achieved by students in an effort to master physical and spiritual skills in school that is manifested in the form of raport in each semester. Learning outcomes are divided into three kinds of learning outcomes, namely: (a). skills and habits; (b). knowledge and understanding; (c). attitudes and ideals, each group can be filled with materials in the school curriculum Haßler, B., Major, L., \& Hennessy, S. (2015).

These three abilities becomethe basis as the ability that must be possessed by the learner to further serve as the basis for the next learning. Revealed that students' learning outcomes in school are 70\% influenced by students' abilities and 30\% are influenced by the environment Moon-Heum Cho, Seung Won Park \& Sang-eun Lee (2019). The factors that influence learning are the internal factor (from within) the student and the external factor (from outside) the student Grey, S., \& Jackson, C. (2020).

The group of religious subjects and noble morals is intended to form learners into human beings who believe and fear The One True God and be noble. Noble morals include ethics, ethics, or morals as the embodiment of religious education. (Permendiknas No. 23 year 2006).

Buddhism (Buddha Dhamma) became a guide for Buddhists in creating a better and dignified life. Various ways to understand religious teachings are through educational, both education in the family, school and community. Religious education is intended to shape learners into human beings who have confidence(saddha)to God almighty, moral and increase the potential of spritual. Buddhist education is a planned and continuous effort to develop the ability of learners to strengthen belief in God almighty and have good morals, as well as increase spiritual potential in accordance with Buddhism. The teaching bellmaterial of Buddhist education includes the following aspects: a. history, b. beliefs (Saddha), c. immorality (Sila), d. Tipitaka Buddhist scriptures (Tripitaka), e. inner development (Samadhi), f. wisdom (Pañ̃a). These material aspects are not all well understood by learners using only textbook media without learning media (Permendiknas No. 22 Year 2006).

The objectives of Buddhist education include the realm of cognitive (knowledge), affective realms (attitudes and values), and psychomotor (deeds). Learners can practice Buddhism well if they also have mastered the cognitive aspects of Buddhism well.

In the processing of information there is an interaction between internal conditions (student circumstances, cognitive processes) and external conditions (stimuli from the environment) and interactions of both will produce learning outcomes. Learning outcomes in the form of capabilities generated by stimulation derived from the environment and cognitive processes carried out by students. In addition, he also said that learning consists of three important components, namely external conditions, namely stimulus from the environment in learning events, internal conditions that describe the internal state of students and cognitive processes of students, and learning outcomes that describe verbal information, intellectual skills, motor skills, attitudes and cognitive strategies Manicka, S., \& Levin, M. (2019).

The learner's interpretation of stimuli is said to be perception. The information that the learner perceives will get attention, then transferred to short-term memory. Expressing 'memory not only the ability to store what he has experienced, but also includes to receive, store, and re-create what he has experienced Gratton, G. (2017).

Learners should pay attention to information if it should be kept in mind. Furthermore students need time to bring all the information received in a short time into consciousness, (Slavin, 2000). Information that does not get the attention of learners will be immediately forgotten, while informasi that gets the attention of students will be transferred to the short-term memory system.Based on information processing theory it is concluded that focused attention is a requirement to process learning materials before entering into the short-term memory of learners and will be passed on to long-term memory for storage.

\section{Research Methods}

The research design used in this study is associative research with a form of casal relationship. This is because this research uses a problem formulation that is associative with causal relationships used to determine the influence of learners' attention to the learning achievements of Buddhist Education. 


\section{A. Population and Research Samples}

The population in this study is all Buddhist students starting from junior high school /vocational level of 54 . Consists of 24 students of Vihara / Sunday Buddhist School Vimala Kirti Girimarto, students of vihara / Sunday school Of Buddha Dhamma Sasana Slogohimo as many as 22, vihara / Sunday school Buddha vihara / Sunday School Buddha Maitri Ratna Giriwoyo as many as 4, and students vihara / Sunday school Buddha Panna Murti Manyaran as many as 2. While the researchers took a sample of $100 \%$ of the existing population of 54 learners because the number is small.

\section{B. Data Collection Techniques and Instruments}

Teknik data collection used is questionnaire technique (questionnaire). This type of questionnaire used is a closed poll, in the sense that the answer is available, the respondent only chooses the answer that has been provided.

Document analysis is done to collect data sourced from archives and documents either in school or outside the school. Documentation is used to obtain information or data related to the learning achievements of Buddhist Education students.

The data collection techniques used in this study are questionnaires and documentation. The scale used is a likert scale that is rated with the following conditions:

SL : Always rated 5

SR : Often rated 4

$\mathrm{KD}$ : Sometimes rated 3

Q : Ever rated 2

TP : Never rated 1

Respondents who answered this research instrument only gave a sign, such as a checklist $(\sqrt{ })$ or a cross $(\mathrm{X})$ on the possible scale of the selected according to the question / statement.

Researchers compiled questionnaire instruments on attention with question indicators: listening, looking at, writing or recording, reading, summarying or underlining, observing tables or diagrams, compiling a working paper, remembering, thinking, and practicing as many as 38 questions to be tested. The trial was conducted to junior high school students up to high school / vocational school in vihara / school Dharma Dwipa Sampung Buddhist Sunday Ponorogo regency of 20 students to find out valid and reliabel instruments before being used to retrieve research data.

Instrument testing using a two-sided test with a significance of 0.05 . The test criteria are as follows: if ${ }_{r}$ calculates $\geq_{\mathrm{r}}$ table (2-sided test with sig. 0.05 ) then the instrument or question items are significantly correlated to the total score (declared valid) and if $\mathrm{r}$ calculates $<_{\mathrm{r}}$ table (2-sided test with sig. 0.05) then the instrument or question items do not correlate significantly to the total score (declared invalid).

Table 1 Instrument Trial Validity Test Results

\begin{tabular}{lcccc}
\hline & $\begin{array}{c}\text { Scale Mean if } \\
\text { Item Deleted }\end{array}$ & $\begin{array}{c}\text { Scale Variance if } \\
\text { Item Deleted }\end{array}$ & $\begin{array}{c}\text { Corrected Item- } \\
\text { Total Correlation }\end{array}$ & $\begin{array}{c}\text { Cronbach's Alpha if } \\
\text { Item Deleted }\end{array}$ \\
\hline PROBLEM1 & 133,38 & 198,517 &, 632 &, 941 \\
\hline PROBLEM2 & 133,06 & 202,729 &, 603 &, 942 \\
\hline PROBLEM3 & 132,88 & 196,117 &, 709 &, 940 \\
\hline PROBLEM4 & 133,38 & 198,517 &, 632 &, 941 \\
\hline PROBLEM5 & 132,81 & 194,029 &, 850 &, 939 \\
\hline PROBLEM6 & 133,00 & 197,867 &, 787 &, 940 \\
\hline PROBLEM7 & 133,13 & 201,450 &, 544 &, 942 \\
\hline PROBLEM8 & 133,06 & 201,796 &, 533 &, 942 \\
\hline PROBLEM9 & 133,25 & 208,867 &, 126 &, 945 \\
\hline PROBLEM10 & 133,38 & 198,517 &, 632 &, 941 \\
\hline PROBLEM11 & 133,25 & 205,933 &, 170 &, 943 \\
\hline PROBLEM12 & 133,19 & 206,029 &, 355 &, 942 \\
\hline PROBLEM13 & 133,13 & 204,117 &, 491 &, 944 \\
\hline PROBLEM14 & 133,25 & 208,067 &, 219 &, 941 \\
\hline PROBLEM15 & 133,19 & 197,363 &, 590 &, 528 \\
\hline PROBLEM16 & 133,13 & 203,583 & & \\
\hline
\end{tabular}




\begin{tabular}{lllll} 
PROBLEM17 & 132,94 & 197,929 &, 819 &, 940 \\
\hline PROBLEM18 & 132,88 & 206,650 &, 176 &, 945 \\
\hline PROBLEM19 & 133,00 & 201,067 &, 593 &, 941 \\
\hline PROBLEM20 & 133,25 & 204,733 &, 448 &, 942 \\
\hline PROBLEM21 & 133,00 & 200,800 &, 609 &, 941 \\
\hline PROBLEM22 & 132,94 & 198,596 &, 649 &, 941 \\
\hline PROBLEM23 & 133,00 & 197,867 &, 787 &, 940 \\
\hline PROBLEM24 & 133,25 & 207,667 &, 246 &, 944 \\
\hline PROBLEM25 & 133,00 & 197,867 &, 787 &, 940 \\
\hline PROBLEM26 & 133,19 & 196,163 &, 411 &, 945 \\
\hline PROBLEM27 & 133,00 & 200,000 &, 658 &, 941 \\
\hline PROBLEM28 & 132,88 & 195,983 &, 826 &, 940 \\
\hline PROBLEM29 & 133,00 & 197,867 &, 787 &, 940 \\
\hline PROBLEM30 & 133,00 & 200,800 &, 609 &, 942 \\
\hline PROBLEM31 & 133,13 & 203,583 &, 528 &, 942 \\
\hline PROBLEM32 & 133,06 & 201,796 &, 533 &, 941 \\
\hline PROBLEM33 & 133,31 & 198,629 &, 613 &, 948 \\
\hline PROBLEM34 & 133,19 & 212,563 &,- 069 &, 941 \\
\hline PROBLEM35 & 133,31 & 198,629 &, 613 &, 940 \\
\hline PROBLEM36 & 132,88 & 195,983 &, 826 &, 941 \\
\hline PROBLEM37 & 132,94 & 198,863 &, 635 &, 940 \\
\hline PROBLEM38 & 132,88 & 195,983 &, 826 & \\
\hline
\end{tabular}

Source: SPSS version 18 results.

From the table above can be seen in Corrected Item - Total Correlation, this is the correlation value obtained. This value is then compared with the value of $r_{\text {table }}, r_{\text {table }}$ is searched at a significance of 0.05 with a 2 -sided test and the amount of data $(n)=20$, then obtained $r_{\text {table }}$ of 0.4438 . From the results of the analysis can be seen that for points $9,11,12,14,18,24,26$, and 34 values less than 0.4438 . Because the correlation coefficients in items 9,11 , $12,14,18,24,26$, and 34 are less than 0.4438 , it can be concluded that the instrument item is invalid. While in other items the value is more than 0.4438 and it can be concluded that the instrument item is valid. Invalid question items are discarded and valid question items are analyzed again using SPSS 18.00 for windows and valid question items are used as research instruments.

\section{Validity and Reliability of Instruments}

Uji validity in this study is using Corrected Item-Total Correlation. This study uses questionnaire data as primary data, so it is necessary to test the statement (questionnaire) step. To know whether or not a validity test is valid. The test criteria is if $r_{\text {calculates }} \geq \mathrm{r} 0.4438$ (2-sided test with sig. 0.05) then the instrument or question items are significantly correlated to the total score (declared valid). The decision criteria is to compare the Corrected Item-Total Correlatioan value greater than 0.4438 then the indicator is valid.

Table 2 Instrument Test Results

\begin{tabular}{lcccc}
\hline & $\begin{array}{c}\text { Scale Mean if } \\
\text { Item Deleted }\end{array}$ & $\begin{array}{c}\text { Scale Variance if } \\
\text { Item Deleted }\end{array}$ & $\begin{array}{c}\text { Corrected Item-Total } \\
\text { Correlation }\end{array}$ & $\begin{array}{c}\text { Cronbach's Alpha if } \\
\text { Item Deleted }\end{array}$ \\
\hline PROBLEM1 & 105,31 & 158,896 &, 664 &, 960 \\
\hline SOAL2 & 105,00 & 163,467 &, 584 &, 960 \\
\hline PROBLEM3 & 104,81 & 157,496 &, 697 &, 959 \\
\hline PROBLEM4 & 105,31 & 158,896 &, 664 &, 960 \\
\hline PROBLEM5 & 104,75 & 155,533 &, 844 &, 958 \\
\hline PROBLEM6 & 104,94 & 159,263 &, 761 &, 959 \\
\hline PROBLEM7 & 105,06 & 162,196 &, 536 &, 960 \\
\hline PROBLEM8 & 105,00 & 161,867 &, 567 &, 960 \\
\hline PROBLEM10 & 105,31 & 158,896 &, 664 &, 960 \\
\hline PROBLEM13 & 105,06 & 164,063 &, 523 &, 960 \\
\hline PROBLEM15 & 105,13 & 157,717 &, 624 &, 960 \\
\hline PROBLEM16 & 105,06 & 164,463 &, 491 &, 961 \\
\hline PROBLEM17 & 104,88 & 158,917 &, 820 &, 958 \\
\hline PROBLEM19 & 104,94 & 161,263 &, 625 &, 960 \\
\hline PROBLEM20 & 105,19 & 164,696 &, 473 &, 961 \\
\hline
\end{tabular}




\begin{tabular}{lllll} 
PROBLEM21 & 104,94 & 161,529 &, 607 &, 960 \\
\hline SOAL22 & 104,88 & 159,717 &, 637 &, 960 \\
\hline PROBLEM23 & 104,94 & 159,263 &, 761 &, 959 \\
\hline PROBLEM25 & 104,94 & 159,263 &, 761 &, 959 \\
\hline PROBLEM27 & 104,94 & 160,729 &, 661 &, 960 \\
\hline PROBLEM28 & 104,81 & 157,496 &, 806 &, 958 \\
\hline PROBLEM29 & 104,94 & 159,263 &, 761 &, 959 \\
\hline PROBLEM30 & 104,94 & 161,529 &, 607 &, 960 \\
\hline PROBLEM31 & 105,06 & 164,463 &, 491 &, 961 \\
\hline PROBLEM32 & 105,00 & 161,867 &, 567 &, 960 \\
\hline PROBLEM33 & 105,25 & 158,733 &, 659 &, 960 \\
\hline PROBLEM35 & 105,25 & 158,733 &, 659 &, 958 \\
\hline PROBLEM36 & 104,81 & 157,496 &, 806 &, 960 \\
\hline PROBLEM37 & 104,88 & 160,117 &, 613 &, 958
\end{tabular}

Source: SPSS version 18 results.

Based on the output of table 2 can be seen Corrected Item - Total Correlation, this is the correlation value obtained. This value is then compared to the $r_{\text {value }}$ of the table (0.4438). From the results of the analysis can be seen all items value more than 0.4438 then it can be concluded that the instrument item is valid.

While the questionnaire was compiled and developed by researchers based on the description of the theory in Chapter II.

Table 3 Research Intrusion Grid

\begin{tabular}{|c|c|c|}
\hline Item Number Indicator & Problem Number & Number of questions \\
\hline Listen & $1,3,2$ & 3 \\
\hline Looked & $5,6,4$ & 3 \\
\hline Write or take notes & 7,8 & 2 \\
\hline Read & $10,11,12,9,13$ & 5 \\
\hline Create a summary or underline & $14,15,16,17$ & 4 \\
\hline Observe a picture & 18,19 & 2 \\
\hline Remember & 20,21 & 2 \\
\hline Think & $22,23,24,25$ & 4 \\
\hline Exercise or practice & 26,27 & 2 \\
\hline Ask & $28,29,30$ & 3 \\
\hline Amount & 30 & 30 \\
\hline
\end{tabular}

Reliability testing is determined from the comparison of the value of the analysis results with the standard alpha coefficient value of 0.60 . Constructs and variables are said to be variable when they have alpha values above 0.60 and vice versa (Imam Ghozali, 2005: 42).

Table 4 Instrument Reliability Test Results

\begin{tabular}{ll}
\hline Cronbach's Alpha & N of Items \\
\hline, 961 & 30 \\
\hline
\end{tabular}

Source: SPSS version 18 results.

Based on table 4 it is known that $\mathrm{N}$ or the number of questions is 30 points. Cronbach's Alpha value of 0.961 indicates that the instrument as a whole is very reliabel.

\section{Data Analysis Techniques}

Data analysis is carried out with the aim of testing hypotheses in order to draw conclusions. In this study is Simple Linear Regression Analysis. The use of this analysis aims to determine the effect of free variables on bound variables, namely between attention to learning (X) to learning outcomes (Y) by using simple linear regression equations with the following formulas: 
$\mathrm{Y}=\mathrm{a}+\beta \mathrm{x}$

Description:

$\mathrm{Y}$ : Variable learning positions

$\beta$ : Coefficient of regression $b$

$\mathrm{X}$ : Student attention variable

a : Coefficient of regression

\section{Research And Discussion Results}

The description of this research data describing the data of learning attention and learning achievements of Buddhism can be seen in the following table:

\section{A. Attention Data B learning}

The results of frequency distribution analysis for learning attention variables can be seen in the following table.

Table 5. Distribution of Learning Attention Frequencies

\begin{tabular}{|l|lllll}
\hline \multicolumn{2}{c}{} & Frequency & Percent & $\begin{array}{l}\text { Valid } \\
\text { Percent }\end{array}$ & $\begin{array}{l}\text { Cumulative } \\
\text { Percent }\end{array}$ \\
\hline \multirow{5}{*}{ Valid } & $110-104$ & 9 & 16,7 & 16,7 & 16,7 \\
\cline { 2 - 6 } & $105-109$ & 10 & 18,5 & 18,5 & 35,2 \\
\cline { 2 - 6 } & $110-114$ & 14 & 25,9 & 25,9 & 61,1 \\
\cline { 2 - 6 } & $115-119$ & 12 & 22,2 & 22,2 & 83,3 \\
\cline { 2 - 6 } & $120-124$ & 5 & 9,3 & 9,3 & 92,6 \\
\cline { 2 - 6 } & $125-129$ & 4 & 7,4 & 7,4 & 100,0 \\
\cline { 2 - 6 } & Total & 54 & 100,0 & 100,0 & \\
\hline
\end{tabular}

Source: SPSS version 18 results.

The frequency distribution of the above attention variables can be seen in the form of the following diagram.

Figure 1. Histogram Distribution of Attention Frequency learning

The diagram above shows that the most learning attention variable data is located at intervals of 110-114 with a frequency of 14 learners or as much as $25.9 \%$ and at least the data is located at intervals of 125-129 with a frequency of 4 learners or $7.4 \%$.

Spss testing technique used to test the validity of attention data in learning is to use Corrected Item-Total Correlation with the help of SPSS version 18.00 program. This test is used to measure the validity and validity of an answer

Tabel 6 Respondents' Answer Validity Test Results

\begin{tabular}{|c|c|c|c|c|}
\hline & \multicolumn{3}{|c|}{ Scale Mean if ItemScale Variance if ItemCorrected } & \multirow{2}{*}{$\begin{array}{c}\text { Item-TotalCronbach's Alpha if Item } \\
\text { Deleted }\end{array}$} \\
\hline & Deleted & Deleted & Correlation & \\
\hline PROBLEM1 & 108,96 & 53,546 & ,536 & 851 \\
\hline PROBLEM2 & 109,04 & 52,187 & ,573 & 849 \\
\hline PROBLEM3 & 108,91 & 55,859 & ,342 & 859 \\
\hline PROBLEM4 & 109,02 & 56,660 & ,489 & 860 \\
\hline PROBLEM5 & 109,02 & 53,981 & ,533 & 852 \\
\hline PROBLEM6 & 108,91 & 53,821 & 531 & ,852 \\
\hline PROBLEM7 & 108,98 & 54,509 & ,407 & ,855 \\
\hline PROBLEM8 & 109,00 & 53,132 & 4,481 & 852 \\
\hline PROBLEM9 & 108,87 & 52,832 &, 537 & 851 \\
\hline PROBLEM10 & 109,02 & 53,905 & ,440 & ,854 \\
\hline PROBLEM11 & 109,02 & 55,264 & ,328 & 857 \\
\hline PROBLEM12 & 108,94 & 51,714 & ,627 & 848 \\
\hline PROBLEM13 & 108,80 & 52,429 & ,634 & ,848 \\
\hline PROBLEM14 & 108,76 & 53,432 &, 542 & ,851 \\
\hline PROBLEM15 & 108,89 & 56,176 &, 352 &, 858 \\
\hline PROBLEM16 & 109,07 & 56,560 & ,374 & 860 \\
\hline PROBLEM17 & 108,93 & 56,410 &, 487 & ,860 \\
\hline PROBLEM18 & 109,09 & 55,557 & ,329 & ,857 \\
\hline PROBLEM19 & 109,04 & 55,999 & ,379 & 858 \\
\hline
\end{tabular}




\begin{tabular}{|c|c|c|c|c|}
\hline PROBLEM20 & 109,02 & 56,509 &, 310 & ,859 \\
\hline PROBLEM21 & 108,93 & 55,730 & ,420 & ,860 \\
\hline PROBLEM22 & 108,98 & 56,811 & ,356 & ,861 \\
\hline PROBLEM24 & 108,91 & 53,520 & ,470 &, 853 \\
\hline PROBLEM25 & 108,91 & 54,312 & ,359 & ,856 \\
\hline PROBLEM26 & 108,85 & 54,393 & ,371 & ,856 \\
\hline PROBLEM28 & 108,94 & 54,657 &, 351 & ,856 \\
\hline PROBLEM29 & 108,96 & 56,829 & ,378 & ,860 \\
\hline PROBLEM30 & 108,94 & 54,582 &, 412 &, 855 \\
\hline
\end{tabular}

Source: SPSS version 18 results.

The test criteria is if $r_{\text {calculates }} \geq r_{0.2681}$ (a 2-sided test with sig. 0.05) then the answer to the question is significantly correlated to the total score (declared valid). The decision criteria is to compare the corrected itemtotal Correlatioan value greater than 0.2681 then the answer is valid.

Reliability testing is determined from the comparison of the value of the analysis results with the standard alpha coefficient value of 0.60 .

Table 7 Respondents' Answer Reliability Test Results

\begin{tabular}{ll}
\hline Cronbach's Alpha & N of Items \\
\hline, 961 & 30 \\
\hline
\end{tabular}

Source: SPSS version 18 results.

Based on table 7, reliability test results can be seen in reliability statisticsoutput. Cronbach's Alpha score of 0.860 indicates that the answers of students at junior high school/vocational level who are Buddhist as a whole are very reliabel.

\section{B. Learning Achievement Data}

Data on buddhist education learning achievements obtained from the document of midterm test scores students of junior high school / vocational school of Buddhism.

The results of frequency distribution analysis for learning achievement variables can be seen in the following table.

Table 8. Distribution of Learning Achievement Frequency

\begin{tabular}{cccccc}
\hline Valid & & Frequency & Percent & Valid Percent & Cumulative Percent \\
\cline { 2 - 6 } & $67-72$ & 2 & 3,7 & 3,7 & 3,7 \\
\cline { 2 - 6 } $73-78$ & 11 & 20,4 & 20,4 & 24,1 \\
\cline { 2 - 6 } & $79-84$ & 9 & 16,7 & 16,7 & 40,7 \\
\cline { 2 - 6 } & $85-90$ & 18 & 33,3 & 33,3 & 74,1 \\
\cline { 2 - 6 } & $91-96$ & 10 & 18,5 & 18,5 & 92,6 \\
\cline { 2 - 6 } & $97-102$ & 4 & 7,4 & 7,4 & 100,0 \\
\cline { 2 - 6 } & Total & 54 & 100,0 & 100,0 & \\
\hline
\end{tabular}

Source: SPSS version 18 results.

The frequency distribution of achievement variables above can be seen in the form of the following diagram.

Gamber 2. Histogram Distribution of Frequency of Learning Achievement

The diagram above shows that the most learning achievement variable data is located at intervals of 85-90 with a frequency of 18 learners or as much as $33.3 \%$ and at least the data is located at intervals of $67-72$ with a frequency of 2 learners or $3.7 \%$.

\section{Analysis Prerequisite Test}

The purpose of normality testing is to find out if the sample being investigated is distributing normally or not. Normality testing criteria is if the level value is significantly greater than $0.05(\mathrm{P}>5 \%)$ then declared normal distribution. Normality test of attention data and achievement is done with shapiro wilk test. Based on normality test results obtained the following data:

Table 9. Learning Attention Data Test Results 


\begin{tabular}{lcccccc}
\hline & \multicolumn{5}{c}{ Cases } \\
\hline & Valid & \multicolumn{2}{c}{ Missing } & \multicolumn{2}{c}{ Total } \\
\hline Attention & $\mathrm{N}$ & Percent & $\mathrm{N}$ & Percent & $\mathrm{N}$ & Percent \\
\hline
\end{tabular}

Source: SPSS version 18 results.

In the table it appears that the $\mathrm{N}$ valid attention variable equals $\mathrm{N}$ total of 54 . Missing o indicates that all data has been processed from all 54 samples.

Table 10.Learning Attention Data Normality Test Results

\begin{tabular}{lcccccc}
\hline \multicolumn{2}{c}{ Kolmogorov-Smirnov $^{\text {a }}$} & \multicolumn{3}{c}{ Shapiro-Wilk } \\
\hline \multicolumn{1}{c}{ Statistics } & Df & Sig. & Statistics & Df & Sig. \\
\hline Attention &, 106 & 54 &, 188 &, 966 & 54 &, 129 \\
\hline a. Lilliefors Significance Correction & & & & \\
\hline
\end{tabular}

Sumber: SPSS version 18 results.

Based on the table it appears that the shapiro wilk value for the attention variable is 0.966 with a probability ( $\mathrm{sig}$ ) of 0.129 . Probability value $>0.05$ then it can be concluded that the data is normally distributed based on shapiro wilk test.

Table 11. Learning Achievement Data Test Results

\begin{tabular}{lcccccc}
\hline & \multicolumn{2}{c}{ Kolmogorov-Smirnov $^{\text {a }}$} & \multicolumn{3}{c}{ Shapiro-Wilk } \\
\hline & Statistics & Df & Sig. & Statistics & Df & Sig. \\
\hline Achievements &, 122 & 54 &, 043 &, 971 & 54 &, 207 \\
\hline \begin{tabular}{llllll} 
a. Lilliefors Significance Correction \\
\hline
\end{tabular}
\end{tabular}

Source: SPSS version 18 results.

In the table it appears that the $\mathrm{N}$ valid attention variable equals $\mathrm{N}$ total of 54 . Missing o indicates that all data has been processed from all 54 samples

Table 12. Normality Test Results of Learning Achievement Data

\begin{tabular}{lcccccc}
\hline & \multicolumn{3}{c}{ Kolmogorov-Smirnov $^{\text {a }}$} & \multicolumn{3}{c}{ Shapiro-Wilk } \\
\hline & Statistics & Df & Sig. & Statistics & Df & Sig. \\
\hline Achievements &, 122 & 54 &, 043 &, 971 & 54 &, 207 \\
\hline a. Lilliefors Significance Correction & & & & & \\
\hline
\end{tabular}

Source: SPSS version 18 results.

Based on the table it appears that the shapiro wilk value for the attention variable is 0.971 with a probability ( sig) of 0.207. Probability value $>0.05$ then it can be concluded that the data is normally distributed based on shapiro wilk test.

The purpose of a linearity test is to determine the relationship between free variables and linearly bound variables or not. Based on ANOVA table in SPSS, will be seen the value of Sig. linearity \& Sig. deviation from linearity of each variable free with bound variables compared to the level of significance $(\alpha)$. The value of Sig. linearity indicates the extent to which free variables are directly proportional in a straight line. If the value of Sig. linearity is less than the significance level $(\alpha)$, then linear regression can be used to explain the influence between existing variables.

While the value of Sig. deviation from linearity indicates what selinier data is used. If the value of Sig. deviation from linearity is greater than the level of significance $(\alpha)$, then linear regression can be used to explain the influence between existing variables. 
Table 13 Data Linearity Test Results

\begin{tabular}{|c|c|c|c|c|c|c|c|}
\hline & & & $\begin{array}{l}\text { Sum } \\
\text { Squares }\end{array}$ & Df & Mean Square & $\mathrm{F}$ & Sig. \\
\hline \multirow{5}{*}{$\begin{array}{l}\text { ACHIEVEMENTS } \\
\text { ATTENTION }\end{array}$} & \multirow{3}{*}{$\begin{array}{l}\text { *Between } \\
\text { Groups }\end{array}$} & (Combined) & 2059,021 & 19 & 108,370 & 2,742 &, 005 \\
\hline & & Linearity & 1531,107 & 1 & 1531,107 & 38,739 &, 000 \\
\hline & & $\begin{array}{l}\text { Deviation } \\
\text { Linearity }\end{array}$ & from $_{527,915}$ & 18 & 29,329 & ,742 & ,746 \\
\hline & \multicolumn{2}{|c|}{ Within Groups } & 1343,812 & 34 & 39,524 & & \\
\hline & \multicolumn{2}{|l|}{ Total } & 3402,833 & 53 & & & \\
\hline
\end{tabular}

Source: SPSS version 18 results.

Based on the results of the table above if the specified $\alpha$ value is $5 \%$, it can be explained that the value of Sig. linearity of the data is $0.000<0.05$ and the value of Sig. deviation from linearity of the data is $0.746>0.05$. So it is concluded that the data is linear.

\section{Data Analysis}

Regression Analysis Results Simple linear regression analysis is used to determine the amount of influence of learning attention variables (X) on the learning achievements of Buddhist Education (Y). The following statistical calculations of simple linear regression analysis can be seen in Table 14.

Table 14. Coefficients Test Results

\begin{tabular}{|c|c|c|c|c|c|c|c|}
\hline \multirow{2}{*}{ Model } & \multicolumn{2}{|c|}{ Unstandardized Coefficients } & $\begin{array}{l}\text { Standardized } \\
\text { Coefficients }\end{array}$ & \multirow{2}{*}{ QQ } & \multirow{2}{*}{ Sig. } & \multicolumn{2}{|c|}{$\begin{array}{l}95.0 \% \text { Confidence } \\
\text { Interval for B }\end{array}$} \\
\hline & B & Std. Error & Beta & & & $\begin{array}{l}\text { Lower } \\
\text { Bound }\end{array}$ & $\begin{array}{l}\text { Upper } \\
\text { Bound }\end{array}$ \\
\hline 1 (Constant) & 5,882 & 12,201 & & 482 & ,632 & $-18,600$ & 30,365 \\
\hline Attention & ,704 & , 108 & 671 & 6,522 & ,000 & ,488 & 921 \\
\hline
\end{tabular}

\section{Source: SPSS version 18 results.}

Table di above shows the results of simple regression equationsas follows: $Y=a+\beta X=5,882+0.704 X$ or Buddhist educational achievement $=5,882+0.704$ (learning attention) The regression model can be interpreted as follows:

1. The constant of 5,882 states that if there are no independent variables or learning attention $(X=0)$, then the achievement of learning Buddhism is 5,882.

2. The coefficient of regression of learning attention increased positively by 0.704 , meaning that if there is a change in learning attention by $1 \%$ will increase the achievement of learning Buddhism education by $70.4 \%$.

$\mathrm{T}$ testing is used to determine the influence of independent variables (learning attention) on dependent variables (buddhist education learning achievements). Significant positive influences can be estimated by

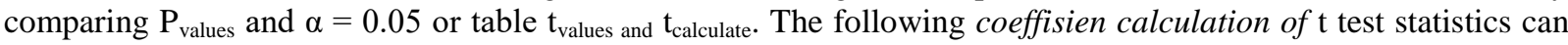
be seen in Table 15.

Table 15. Coefficients Test Results

\begin{tabular}{llllllll}
\hline Model & $\begin{array}{l}\text { Unstandardized } \\
\text { Coefficients }\end{array}$ & $\begin{array}{l}\text { Standardized } \\
\text { Coefficients }\end{array}$ & Q & Sig. & $\begin{array}{l}\text { 95.0\% } \\
\text { Interval for B }\end{array}$ \\
\cline { 2 - 8 } & $\mathrm{B}$ & Std. Error & Beta & & $\begin{array}{l}\text { Lower } \\
\text { Bound }\end{array}$ & $\begin{array}{l}\text { Upper } \\
\text { Bound }\end{array}$ \\
\hline 1 (Constant) & 5,882 & 12,201 & &, 482 &, 632 & $-18,600$ & 30,365 \\
\hline Attention &, 704 &, 108 &, 671 & 6,522 &, 000 &, 488 &, 921 \\
\hline a. Dependent Variable: ACHIEVEMENT & & & & & \\
\hline
\end{tabular}

Source: SPSS version 18 results. 


\section{Test Criteria}

$\mathrm{H}_{0}=\beta \leq 0$, i.e. $\mathrm{X}$ has no positive effect on $\mathrm{Y}$.

$\mathrm{H}_{1}=\beta>0$, i.e. $\mathrm{X}$ has a positive effect on $\mathrm{Y}$.

The test result $t$ for variable $X$ (learning attention) ${ }_{\text {obtained }}$ the value $t$ calculate $=6522$ with a level of $P_{\text {value }}=$ 0.000 , using a significant limit of $\alpha=0.05$ in the can $t_{\text {table }}(95 \% ; 5)$ of 2,007 . From these results, the test criteria are $\mathrm{t}_{\text {calculate }}>\mathrm{t}$ table or $\mathrm{P}_{\text {value }}<\alpha$ which means $\mathrm{H}_{0}$ is rejected and $\mathrm{H}_{1}$ is accepted. Thus the hypothesis of the test $\mathrm{t}$ variables of learning attention has a positive and acceptable effect, the direction of positive regression coefficient means that learning attention has a significant influence on the learning achievements of Buddhism education. It can be concluded that better indicators of learning attention will improve the learning achievements of Buddhism.

$\mathrm{F}$ testing is used to predict whether the regression model can be used to predict the educational achievements of Buddhism. Significant positive influences can be estimated by comparing $\mathrm{P}_{\text {value }}$ and $\alpha=0.05$ or table $\mathrm{F}_{\text {value }}$ $\operatorname{and}_{\text {calculate }} \mathrm{F}$. The following statistical calculation of Anova Test $\mathrm{F}$ can be seen in Table 16.

Table 16. Anova Test Results

\begin{tabular}{|c|c|c|c|c|c|c|}
\hline \multicolumn{2}{|c|}{ Model } & \multirow{2}{*}{$-\frac{\text { Sum of Squares }}{1531,107}$} & \multirow{2}{*}{$\frac{\mathrm{Df}}{1}$} & \multirow{2}{*}{$\frac{\text { Mean Square }}{1531,107}$} & \multirow{2}{*}{$\frac{F}{42,537}$} & \multirow{2}{*}{$\frac{\text { Sig. }}{.000^{\mathrm{a}}}$} \\
\hline$\overline{1}$ & Regression & & & & & \\
\hline & Residual & 1871,727 & 52 & 35,995 & & \\
\hline & Total & 3402,833 & 53 & & & \\
\hline \multicolumn{7}{|c|}{ a. Predictors: (Constant), ATTENTION } \\
\hline
\end{tabular}

Source: SPSS version 18 results.

$\mathrm{H}_{\mathrm{o}}: \beta=0$, i.e. No influence

the linear between learning attention

with religious education achievements

Buddha.

$H_{1}: \beta=0$, i.e. there is a linear influence

between the attention of learning and

achievements of Buddhism.

The Anova test result above reads the calculated $F_{\text {value }}$ of 42,537 with a significance of 0.000 because the probability $(0.000)$ is much less than 0.05 (in this case using a significance level or $\alpha=5 \%$ ) then the regression model can be used to predict the learning achievements of Buddhist education.

The coefficient of determination reflects the effect of independent variable changes in running changes to dependent variables together, with the aim of measuring the correctness and goodness of the relationships between variables in the model used. The amount of $R^{2}$ values ranges from $0<R^{2}<1$. If the value of $R^{2}$ is getting closer to one then the proposed model is said to be good because the higher the variation of dependent variables that can be explained by independent variables.

Based on the estimated model of regression equation that has been done above obtained the value of the coefficient of determination $\mathrm{R}^{2}$ report in table 17 as follows:

Table 17. Summary Model Results

\begin{tabular}{|c|c|c|c|c|c|c|c|c|c|c|}
\hline \multirow{2}{*}{ Model } & \multirow[b]{2}{*}{$\mathrm{R}$} & \multirow[b]{2}{*}{ R Square } & \multirow{2}{*}{$\begin{array}{l}\text { Adjusted } \\
\text { Square }\end{array}$} & \multicolumn{3}{|c|}{ RStd. Error of $\frac{\text { Change Statistics }}{\mathrm{D}}$} & \multirow[b]{2}{*}{ df1 } & \multirow[b]{2}{*}{ df 2} & \multirow[b]{2}{*}{$\begin{array}{l}\text { Sig. } \\
\text { Change }\end{array}$} & \\
\hline & & & & the Estimate & $\begin{array}{l}\mathrm{R} \text { Squ } \\
\text { Change }\end{array}$ & ${ }^{e}$ F Change & & & & \\
\hline dimension 0 & $1.671^{\mathrm{a}}$ &, 450 & ,439 & 6,000 & 450 & 42,537 & 1 & 52 &, 000 & \\
\hline \multicolumn{11}{|c|}{ a. Predictors: (Constant), ATTENTION } \\
\hline \multicolumn{11}{|c|}{ b. Dependent Variable: ACHIEVEMENT } \\
\hline
\end{tabular}

Source: SPSS version 18 results. 
Table 17 shows the Simple Linear Regression Result of the Model Summary $R$ correlation coefficient which indicates the degree of relationship between independent variables to dependent variables of 0.671 or close to 1 meaning there is a strong relationship, and $\mathrm{R}$ square or coefficient of determination $\mathrm{R}^{2 \text { shows }}$ a contribution of 0.450 or $45 \%$ of the learning attention to the learning achievements of Buddhist education while the remaining 0.550 or $55 \%$ is a contribution from other factors not studied such as the use of methods, and media.

\section{E. Discussion}

The discussion of the influence of learning attention on Buddhist educational achievements begins with a discussion about the influence of learning attention on the learning achievements of Buddhism education, in this case the attention of learners. The results of statistical testing using simple linear regression showed that learning attention influenced the achievements of Buddhist education, in this case the attention of learners, then based on the results of research in the field that was strengthened by secondary data sourced by Teachers of Buddhist Education, showed that learning attention had a positive effect on the achievement of learning Buddhism education.

Statistical test results have shown that a significant level of learning attention of 0.704 is smaller than the significant level of 0.05 so as to prove that learning attention has a positive effect on Buddhist educational achievement. If the attention to learning increases by 0.704 , it will increase the achievement of learning Buddhism education by $70.4 \%$.

This is in accordance with the theory of information processing that focused attention is a requirement for processing learning materials. Meditation is an effort made to train the mind to be focused and always pay attention to the changes and movements of one's thoughts Britton, W. B., Davis, J. H., Loucks, E. B., Peterson, B., Cullen, B. H., Reuter, L., Lindahl, J. R. (2018). A person's memory performance is determined by how much storage capacity they have and how strong their attention is to objects Souza, A. S., Rerko, L., Lin, H.-Y., \& Oberauer, K. (2014). Lack of attention in the implementation of learning will affect a child's learning achievement Singh, M. K. (2015). Students' attention in participating in learning will influence and determine student achievement Fenger, T. N. (1998), Jong, P. F. (1993).

\section{Conclusions And Suggestions}

\section{Infers}

1. This research proves that the influence of learning attention on the learning achievements of Buddhist education belongs to a strong category.

2. Based on the results of the researchers, it was found that the effect of learning on learning achievement in Buddhism education in Wonogiri Regency in 2014 was 45\%. The remaining 55\% can be relied on by other factors.

\section{Advice}

1. For students.

The attention of learners in learning needs to be improved, as it affects learning achievement.

\section{For teachers.}

Teachers should try to increase the awareness of students.

\section{For Schools}

It is necessary to use tools or learning facilities to attract the attention of its learners, so that students will be happy to take Buddhist education lessons.

\section{References}

Bellas, F., Becerra, J. A., \& Duro, R. J. (n.d.). Internal and External Memory in Neuroevolution for Learning in Non-stationary Problems. From Animals to Animats 10, 62-72. doi:10.1007/978-3-540-69134-1_7

Benton, D. (1999). Applied human relationship an organizational approach. London: Publisher.

BNSP. (2006). Permendiknas No. 22 Year 2006 on Content Standards for Primary and Secondary Education Units. Jakarta.

Brinson, J. R. (2015). Learning outcome achievement in non-traditional (virtual and remote) versus traditional (hands-on) laboratories: A review of the empirical research. Computers \& Education, 87, $218-237$. doi:10.1016/j.compedu.2015.07.003 
Britton, W. B., Davis, J. H., Loucks, E. B., Peterson, B., Cullen, B. H., Reuter, L., ... Lindahl, J. R. (2018). Dismantling Mindfulness-Based Cognitive Therapy: Creation and validation of 8-week focused attention and open monitoring interventions within a 3 -armed randomized controlled trial. Behaviour Research and Therapy, 101, 92-107. doi:10.1016/j.brat.2017.09.010.

Cordner, C. (2016). Lessons of Murdochian Attention. Sophia, 55(2), 197-213. doi:10.1007/s11841-016-0540-2

Dao, P., Iwashita, N., \& Gatbonton, E. (2016). Learner attention to form in ACCESS task-based interaction. Language Teaching Research, 21(4), 454-479. doi:10.1177/1362168816651462

DA, Z., ENGELBERG, J., \& GAO, P. (2011). In Search of Attention. The Journal of Finance, 66(5), 1461-1499. doi:10.1111/j.1540-6261.2011.01679.x

Fenger, T. N. (1998). Visual-motor Integration and its Relation to EEG Neurofeedback Brain Wave Patterns, Reading, Spelling, and Arithmetic Achievement in Attention Deficit Disordered and Learning Disabled Students. Journal of Neurotherapy, 3(1), 9-18. doi:10.1300/j184v03n01_02

Gareeva, A. E., Sharafiev, R. R., Akhmetova, E. A., Nasibullin, T. R., Fakhurtdinova, Z. R., Yuldashev, V. L., \& Asadullin, A. R. (2020). Combined Influences of Genetic Factors and Attention Deficit Hyperactivity Disorder on the Development of Dependence on Synthetic Cannabinoids. Neuroscience and Behavioral Physiology. doi:10.1007/s11055-020-01029-3

Good, C.V. (1945). Dictionary of education. New York: McGraw-Hill Book Company.

Gratton, G. (2017). Brain reflections: A circuit-based framework for understanding information processing and cognitive control. Psychophysiology, 55(3), e13038. doi:10.1111/psyp.13038

Grey, S., \& Jackson, C. (2020). The Effects of Learners' Perceptions and Affective Factors on L2 Learning Outcomes. The Canadian Modern Language Review, 76(1), 2-30. doi:10.3138/cmlr.2018-0209

Haßler, B., Major, L., \& Hennessy, S. (2015). Tablet use in schools: a critical review of the evidence for learning outcomes. Journal of Computer Assisted Learning, 32(2), 139-156. doi:10.1111/jcal.12123

Hoy, A.W. (2007). Educational psychology (10years ed). New York: Pearson.

Jong, P. F. (1993). The relationship between students' behaviour at home and attention and achievement in elementary school. British Journal of Educational Psychology, 63(2), 201-213. doi:10.1111/j.20448279.1993.tb01052.x

Larouche, M., Côté, G., Bélisle, D., \& Lorrain, D. (2014). Kind attention and non-judgment in mindfulness-based cognitive therapy applied to the treatment of insomnia: State of knowledge. Pathologie Biologie, 62(5), 284291. doi:10.1016/j.patbio.2014.07.002

Manicka, S., \& Levin, M. (2019). The Cognitive Lens: a primer on conceptual tools for analysing information processing in developmental and regenerative morphogenesis. Philosophical Transactions of the Royal Society B: Biological Sciences, 374(1774), 20180369. doi:10.1098/rstb.2018.0369

Ma, S., Sigal, L., \& Sclaroff, S. (2016). Learning Activity Progression in LSTMs for Activity Detection and Early Detection. 2016 IEEE Conference on Computer Vision and Pattern Recognition (CVPR). doi:10.1109/cvpr.2016.214

Miller, P.H. (1993). Theories of developmental psychology (3rd Ed). New York: W.H. Freeman \& Co.

Moon-Heum Cho, Seung Won Park \& Sang-eun Lee (2019): Student characteristics and learning and teaching factors predicting affective and motivational outcomes inflipped college classrooms, Studies in Higher Education, DOI: 10.1080/03075079.2019.1643303

Moran, A. (2017). Attention and Concentration Training in Sport. Reference Module in Neuroscience and Biobehavioral Psychology. doi:10.1016/b978-0-12-809324-5.05476-6

Muijs, D., \& Reynolds, D. (2011). Effective Teaching: Evidence and Practice (3rd ed.). Los Angels, CA: Sage

Rusmita Kurniati. (2009). Penergetic Peer Teaching Method To increase Students' Attention to Biology Materials Of High School Students Class X. Surakarta: FKIP UNS. Retrieved.

Sinclair, P. M., Kable, A., Levett-Jones, T., \& Booth, D. (2016). The effectiveness of Internet-based e-learning on clinician behaviour and patient outcomes: A systematic review. International Journal of Nursing Studies, 57, 70-81. doi:10.1016/j.ijnurstu.2016.01.011

Singh, M. K. (2015). Inattentive Achievement: The Challenges and Opportunities of Learning With AttentionDeficit/Hyperactivity Disorder. Journal of the American Academy of Child \& Adolescent Psychiatry, 54(5), 348-349. doi:10.1016/j.jaac.2015.02.014

Skwarchuk, S.-L., Sowinski, C., \& LeFevre, J.-A. (2014). Formal and informal home learning activities in relation to children's early numeracy and literacy skills: The development of a home numeracy model. Journal of Experimental Child Psychology, 121, 63-84. doi:10.1016/j.jecp.2013.11.006

Slavin, R.E. (2000). Educational psychology: Theory and practice (6th ed). Needham Heights, MA: Allyn and Bacon.

Sobocan, M., Turk, N., Dinevski, D., Hojs, R., \& Pecovnik Balon, B. (2017). Problem-based learning in internal medicine: virtual patients or paper-based problems? Internal Medicine Journal, 47(1), 99-103. doi:10.1111/imj.13304. 
Souza, A. S., Rerko, L., Lin, H.-Y., \& Oberauer, K. (2014). Focused attention improves working memory: implications for flexible-resource and discrete-capacity models. Attention, Perception, \& Psychophysics, 76(7), 2080-2102. doi:10.3758/s13414-014-0687-2

Stavrinos, G., Iliadou, V.-M., Edwards, L., Sirimanna, T., \& Bamiou, D.-E. (2018). The Relationship between Types of Attention and Auditory Processing Skills: Reconsidering Auditory Processing Disorder Diagnosis. Frontiers in Psychology, 9. doi:10.3389/fpsyg.2018.00034

Teixeira, A. R., Tome, A., Roseiro, L., \& Gomes, A. (2018). Attention and concentration in normal and deaf gamers. 2018 IEEE International Conference on Bioinformatics and Biomedicine (BIBM). doi:10.1109/bibm.2018.8621513

Tina Afiatin. (2001). Learn experiences to improve memory. Anima, Indonesian Psychological Journal. Vol. 17. No. 1. 26-35.

Winkel, W.S. (1989). Teaching psychology. Jakarta: Gramedia.Anglin, G. J. (1995). Instructional technology, past, present and future. Colorado: Libraries Unlimited Inc. 